Rok XV (2020) | 2 (30) | S. 245-256

https://doi.org/10.12797/LV.15.2020.30.18

\author{
Jan Sokołowski (D) \\ Uniwersytet Wrocławski, Wrocław \\ jansokol44@gmail.com
}

\title{
KRAKOWSKO-LWOWSKIE KORZENIE WROCŁAWSKIEJ SLAWISTYKI
}

\begin{abstract}
Słowa klucze: historia wrocławskiej slawistyki, Uniwersytet Jagielloński, Uniwersytet Jana Kazimierza Keywords: history of Wrocław Slavic studies, Jagiellonian University, John Casimir University
\end{abstract}

W artykule Geneza i początki Studium Słowiańskiego UJ Mirosław Skarżyński (2019) pokazał, jak wielkie znaczenie dla rozwoju polskiej slawistyki miała trwająca ponad ćwierć wieku działalność tej instytucji. Autor zwrócił m.in. uwagę na to, że należący do przedwojennego pokolenia slawistów absolwenci i współpracownicy Studium Słowiańskiego oraz wykształceni już po wojnie ich młodsi koledzy swoją działalnością naukową i organizacyjną w sposób znaczący przyczynili się do rozwoju badań slawistycznych w Polsce, a w pewnej mierze także za granicą. W artykule zamierzam przedstawić rolę językoznawców slawistów, którzy kształcili się bądź uzyskali stopnie naukowe w Studium Słowiańskim UJ i na Uniwersytecie Jana Kazimierza we Lwowie, $\mathrm{w}$ budowaniu slawistyki i polonistyki językoznawczej oraz organizacji życia naukowego na Uniwersytecie Wrocławskim bezpośrednio po zakończeniu II wojny światowej ${ }^{1}$.

Jak wiadomo, idea utworzenia slawistyki na polskim Uniwersytecie Wrocławskim zrodziła się w Krakowie, w ostatnich miesiącach II wojny światowej. Do jej urzeczywistnienia w sposób wybitny przyczynili się przedstawiciele lwowskiej wspólnoty naukowej, byli profesorowie Uniwersytetu Jana Kazimierza, którzy, podobnie jak

1 Niniejszy artykuł jest poszerzoną wersją referatu wygłoszonego 22 października 2018 r. w Krakowie na sesji zorganizowanej przez Instytut Filologii Słowiańskiej Uniwersytetu Jagiellońskiego z okazji jubileuszu 200-lecia krakowskiej slawistyki. W tekście opieram się głównie na materiałach Zespołu Akt Osobowych Archiwum Uniwersytetu Wrocławskiego (dalej: AUWr). 
ich koledzy z Politechniki Lwowskiej, znaleźli schronienie w Krakowie (Wrzesiński 2002: 202-203). Już 9 maja 1945 r., trzy dni po kapitulacji Festung Breslau, do pełnego ruin i zgliszcz miasta przybyła z Krakowa Grupa Naukowo-Kulturalna, na której czele stał prof. Stanisław Kulczyński, biolog i botanik, rektor Uniwersytetu Jana Kazimierza w latach 1936-1938 (ibid.: 204-205). Jednym z najważniejszych zadań Grupy było zorganizowanie w mieście szkolnictwa wyższego. Stało się to możliwe z chwilą wydania 24 sierpnia 1945 r. dekretu Rządu Jedności Narodowej, który stanowił „o przekształceniu Uniwersytetu Wrocławskiego i Politechniki Wrocławskiej na polskie państwowe szkoły akademickie" (Dekret ${ }^{2}$ ). Dekret stworzył niezbędną podstawę prawną powołania i dalszego funkcjonowania uczelni. W dniu 3 września 1945 r. minister oświaty powierzył prof. S. Kulczyńskiemu funkcję rektora Uniwersytetu i Politechniki we Wrocławiu. Zgodnie z dekretem Uniwersytet tworzyło sześć wydziałów, w tym Wydział Humanistyczny, na którym jesienią 1945 r. zostały uruchomione studia w zakresie filologii polskiej i słowiańskiej.

Decyzje te poprzedzone były dyskusjami i sporami nad wyborem miejsca dla przyszłego uniwersytetu na Ziemiach Zachodnich. Koncepcja powołania do życia Uniwersytetu i Politechniki we Wrocławiu ukształtowała się w planach Tymczasowego Rządu Jedności Narodowej w lutym 1945 r., a potwierdzona została w marcu tegoż roku (Wrzesiński 2002: 202)ㄹ․ W Krakowie został powołany Komitet Organizacyjny Wydziału Humanistycznego Uniwersytetu Wrocławskiego, w którego skład weszli również profesorowie nauk humanistycznych z Uniwersytetu Jagiellońskiego. Na pierwszym posiedzeniu Komitetu, które odbyło się 29 czerwca pod przewodnictwem prof. Witolda Taszyckiego, przedstawiono propozycję struktury Wydziału Humanistycznego przyszłego Uniwersytetu we Wrocławiu. Wydział miał obejmować kilkanaście jednoosobowych katedr, w tym trzy katedry polonistyki i trzy katedry slawistyki (ibid.: 207-208).

W dniu 8 października 1945 r. prof. S. Kulczyński zwrócił się do ministra oświaty z wnioskiem o mianowanie pierwszych profesorów wrocławskiej uczelni. Wśród kandydatów był m.in. W. Taszycki, któremu przedstawiono propozycję objęcia Katedry Języka Polskiego. Ostatecznie jednak Taszycki nie zdecydował się na wyjazd do Wrocławia i podjął pracę na Uniwersytecie Jagiellońskim (ibid.: 210) ${ }^{4}$.

2 http://prawo.sejm.gov.pl/isap.nsf/Doc.Details.xsp?id=WDU19450340207.

3 Stanisław Rospond tak pisał o tym w swoich wspomnieniach: „Jeszcze przed majem 1945 r., kiedy Festung Breslau bronił się zajadle, »lwowiacy« debatowali z profesorem Kulczyńskim na czele, mając alternatywę, Katowice i sąsiednie miasta lub Wrocław jako siedziba alma mater Silesiae. Ma się rozumieć, że wszystkich - pomimo hiobowych wieści o ruinach i zgliszczach Wrocławia urzekł gród Wrocisława. Na tych zebraniach dolewał oliwy do ognia zapału znawca nazewnictwa śląskiego i pierwiosnków piśmienniczych. Padała ta i owa etymologia nazewnicza" (Rospond 2010: 41).

4 Zob. na ten temat Rospond: „Najpierw prof. W. Taszycki miał objąć katedrę języka polskiego, ja zaś języków słowiańskich. Ponieważ prof. Taszycki zrezygnował z tego, wybierając Kraków, dlate- 
Jako pierwszy z grona slawistów i polonistów w listopadzie $1945 \mathrm{r}$. przyjechał do Wrocławia 39-letni wtedy Stanisław Rospond. Nieco później, zachęceni przez Rosponda, przyjechali Leszek Ossowski i Stanisław Bąk. Po roku dołączył do nich Władysław Kuraszkiewicz. W chwili przyjazdu do Wrocławia językoznawcy ci byli już dojrzałymi uczonymi, gruntownie przygotowanymi do pracy w dziedzinie językoznawstwa polskiego i słowiańskiego oraz do realizacji trudnych zadań organizacyjnych związanych z tworzeniem od podstaw nowego ośrodka naukowego. Wszyscy uzyskali wykształcenie pod kierunkiem najwybitniejszych polskich, a niektórzy także zagranicznych, językoznawców slawistów. W momencie podjęcia pracy na Uniwersytecie każdy z nich legitymował się już poważnym dorobkiem ${ }^{5}$.

Urodzony w podkrakowskich Liszkach S. Rospond odbył studia w zakresie filologii polskiej na Uniwersytecie Jagiellońskim, gdzie kształcił się pod kierunkiem Jana Łosia, Kazimierza Nitscha, Jana Rozwadowskiego i Tadeusza Lehra-Spławińskiego ${ }^{6}$. Studia ukończył w roku 1929 i jeszcze w tym samym roku doktoryzował się na podstawie rygorozum oraz pracy doktorskiej Zachodnio-słowiańskie nazwy miejscowe z sufiksem -sk//-sko. W latach 1929-1931 pracował jako lektor języka polskiego na uniwersytecie w Lyonie. W latach 1931-1933 jako stypendysta rządu jugosłowiańskiego przebywał w Belgradzie, przygotowując rozprawę habilitacyjną. W latach 1933-1936 pracował jako nauczyciel w szkole średniej, ogłaszając prace z zakresu językoznawstwa polskiego i słowiańskiego oraz literatur słowiańskich. W roku 1936 podjął pracę jako starszy asystent w Katedrze Języka Polskiego w Uniwersytecie Jana Kazimierza we Lwowie. Habilitował się w roku 1937 na Uniwersytecie Jagiellońskim w zakresie językoznawstwa słowiańskiego na podstawie rozprawy o patronimicznych nazwach miejscowych pt. Południowo-słowianskie nazwy miejscowe $z$ sufiksem -itj-. W latach 1939-1941 jako docent wykładał język polski na Uniwersytecie we Lwowie. Wiosną 1945 r. podjął pracę w Studium Słowiańskim UJ, ale już jesienią tego roku przeniósł się do Wrocławia, gdzie w listopadzie objął stanowisko profesora nadzwyczajnego na Wydziale Humanistycznym w powołanym właśnie do życia Uniwersytecie. We Wrocławiu młody uczony wziął na siebie trud zorganizowania Instytutu Filologii Polskiej i Słowiańskiej i został jego pierwszym kierownikiem, obejmując jednocześnie Katedrę Języka Polskiego.

go mnie przypadł zaszczyt zorganizowania Katedry Języka Polskiego i w ogóle językoznawstwa" (Rospond 2010: 41).

5 Szerzej o działalności slawistycznej Kuraszkiewicza, Ossowskiego i Rosponda w związku z ich pracą na Uniwersytecie Wrocławskim pisałem w osobnym artykule, w którym przedstawiłem zwięzły zarys rozwoju językoznawstwa słowiańskiego we Wrocławiu w latach 1945-2010 (Sokołowski 2015).

6 W życiorysie z 17 lutego 1951 r. Rospond pisał: „Po ukończeniu szkoły elementarnej we wsi rodzinnej uczęszczałem do gimnazjum w Krakowie, które ukończyłem w 1925 r. Po złożeniu matury w tymże roku zapisałem się na Wydział Filozoficzny Uniwersytetu Jagiellońskiego na polonistykę. Ze względu na zainteresowania językoznawcze ukończyłem w 1929 r. magisterium z filologii polskiej, oddając pracę z zakresu językoznawstwa" (AUWr, Sygn. 138/Stanisław Rospond, s. 11). 
Pierwszym powojennym latom polonistyki i slawistyki wrocławskiej poświęcił Rospond fragment niewielkiej książki wspomnieniowej Moja droga do Śląska wydanej przez jego syna Stanisława Rosponda CM. Mniej więcej połowa tekstu (8o stron) poświęcona jest pracy uczonego we Wrocławiu i w Opolu. Wśród wiadomości, jakie książeczka ta przynosi, cenne są zwłaszcza informacje dotyczące organizacji Instytutu Filologii Polskiej i Słowiańskiej, który do 1951 r. mieścił się w budynku dawnego pałacu Książąt Legnicko-Brzeskich przy ul. Szewskiej 49. Wcześniej było tam Seminarium Slawistyczne kierowane przez znanego niemieckiego slawistę Paula Dielsa, autora prac dotyczących języka staro-cerkiewno-słowiańskiego, wydawcę Kazań świętokrzyskich.

Sam Rospond tak pisze o początkach swej pracy we Wrocławiu:

z nominacją na profesora nadzwyczajnego podpisaną przez przedstawiciela Rządu i pierwszego rektora Wszechnicy Wrocławskiej prof. dr. Stanisława Kulczyńskiego rozpocząłem akcję organizacyjną, zabezpieczającą księgozbiór slawistyczny oraz polonistyczny językoznawczy, szczęśliwie ocalały w poniemieckim Slavisches Institut (ul. Szewska 49, II p.) kierowanym przez P. Dielsa. Pierwsze kroki skierowałem na ul. Szewską. [...] Los okazał się przyjazny dla przyszłej językoznawczej polonistyki wrocławskiej, też slawistyki. Prof. Diels i jeszcze jego poprzednicy (W. Nehring) zgromadzili pokaźny księgozbiór, bogaty w czasopisma, słowniki i podstawowe prace językoznawcze. [...] W masywnym biurku Dielsa znalazłem nawet księgę uczestników seminarium Nehringa ze starannie odnotowaną tematyką (Rospond 2010: 44-45).

W porządkowaniu i katalogowaniu księgozbioru poniemieckiego pomagał Rospondowi Zbigniew Gołąb, który przyjechał do Wrocławia, by kontynuować studia rozpoczęte w 1943 r. w warunkach konspiracyjnych na Uniwersytecie Jagiellońskim. Już w listopadzie 1945 r. Rospond mógł wygłosić pierwszy wykład dla spragnionej wiedzy garstki studentów. Temat wykładu brzmiał: „Polskość Śląska w świetle języka” (ibid.: 46).

Rospond pozostawił po sobie bogaty i różnorodny dorobek naukowy, obejmujący ponad 600 prac, w tym 55 książek. Badacze spuścizny naukowo-badawczej S. Rosponda wskazują trzy wielkie obszary jego zainteresowań: 1) onomastyka polska i słowiańska; 2) historia języka polskiego ze szczególnym uwzględnieniem dziejów polszczyzny na Śląsku; 3) dialektologia (głównie historyczna). Jak pisał S. Bąk w dedykowanej Rospondowi księdze jubileuszowej, widać w tym wpływ jego krakowskich mistrzów, przede wszystkim J. Łosia, K. Nitscha, J. Rozwadowskiego i „w pewnej mierze młodszego od nich W. Taszyckiego" (Bąk 1966: 9).

Stanisław Rospond zasłużył się również jako wybitny organizator życia naukowego we Wrocławiu i Opolu ${ }^{7}$. Z jego to inicjatywy przyjechali do Wrocławia: Leszek Ossowski, Władysław Kuraszkiewicz, Marian Jakóbiec.

7 S. Bąk tak o tym pisał: „A ileż ma Mu do zawdzięczenia Uniwersytet Wrocławski. Już sam fakt, że opuścił spokojny i niezniszczony Kraków, macierzysty Kraków, a wybrał się do spalonego, peł- 
Niedługo po Rospondzie przyjechał z Krakowa L. Ossowski, który mianowanie na profesora nadzwyczajnego Uniwersytetu Wrocławskiego otrzymał w styczniu 1946 r. Ossowski studiował początkowo w Poznaniu i już na I roku studiów poświęcił się językowi rosyjskiemu i białoruskiemu. Kształcił się pod kierunkiem Henryka Ułaszyna, Edwarda Klicha i Mikołaja Rudnickiego. Na zakończenie studiów Ossowski przeniósł się na Uniwersytet Jagielloński, gdzie pogłębiał wiedzę pod kierunkiem Tadeusza Lehra-Spławińskiego, Jana Ziłyńskiego i Jana Rozwadowskiego. Stopień magistra i doktora filozofii uzyskał w 1932 r. na Uniwersytecie Jagiellońskim. Lata 1932-1934 spędził w Sofii jako stypendysta rządu bułgarskiego. Uzupełniał tam wykształcenie pod kierunkiem takich uczonych, jak Stefan Mladenov, Ljubomir Miletič i Stojan Romanski. Po powrocie do Polski przez rok był lektorem języka białoruskiego na Uniwersytecie Jagiellońskim. W latach 1935-1940 pracował jako lektor języka bułgarskiego na Uniwersytecie we Lwowie. Od 12 października 1940 r. do 22 czerwca 1941 r. był zatrudniony na stanowisku docenta w Katedrze Filologii Słowiańskiej Uniwersytetu im. Iwana Franki. Podczas okupacji Ossowski przez pewien czas mieszkał i pracował w Jaśle, chociaż niemiecki polskojęzyczny dziennik „Goniec Krakowski” z 30 listopada 1943 r. wymienia jego nazwisko na liście ponad 20 polskich uczonych deportowanych do ZSRR i tam najprawdopodobniej zgładzonych. Na szczęście w wypadku Ossowskiego informacja ta okazała się nieprawdziwa. Po wojnie, od 1 lutego do 15 września 1945 r., pracował w Studium Słowiańskim Uniwersytetu Jagiellońskiego, kolejno na stanowiskach starszego asystenta, adiunkta, a po habilitacji w roku 1945 - docenta. We Wrocławiu Ossowski objął Katedrę Filologii Wschodniosłowiańskiej. W okresie przedwojennym głównym przedmiotem jego zainteresowań badawczych były języki ruskie, przede wszystkim język białoruski. W latach powojennych w centrum jego zainteresowań znalazł się język rosyjski. Wypowiadał się też w kwestii praojczyzny Słowian. Na Uniwersytecie Wrocławskim pracował do 1964 r., po czym przeniósł się do Poznania.

W dniu 1 lutego 1946 r. stanowisko adiunkta w Instytucie Filologii Polskiej i Słowiańskiej Uniwersytetu Wrocławskiego objął S. Bąk, uczeń T. Lehra-Spławińskiego, pod którego kierownictwem studiował polonistykę i slawistykę na Uniwersytecie Jana Kazimierza we Lwowie, gdzie w 1926 r. uzyskał doktorat. Do 1928 r. Bąk

nego ruin Wrocławia, dużo mówi o Jego energii i przedsiębiorczości oraz świadczy dobrze o Jego postawie obywatelskiej i zrozumieniu ważności chwili dziejowej. Objąwszy tu Katedrę Języka Polskiego, zabezpieczył pozostałą po Niemcach część księgozbioru i wespół ze śp. Tadeuszem Mikulskim zorganizował Instytut Filologii Polskiej i Słowiańskiej, rozbity później na Katedrę Historii Literatury Polskiej oraz Zespół Katedr Językoznawstwa. [...] S. Rospond dążył do rozbudowania studiów językoznawczych, ściągając do Wrocławia samodzielnych pracowników naukowych (L. Ossowskiego, W. Kuraszkiewicza, M. Jakóbca) oraz siły pomocnicze (St. Bąka, Zb. Gołąba, Karola Heintscha, Janinę Loretównę)" (Bąk 1966: 20). O dorobku badawczym i dokonaniach organizacyjnych S. Rosponda zob. też: Łobodzińska 2004: 695-703, 2010: 15-20, 2017: 87-95. 
pracował jako asystent na Uniwersytecie Jana Kazimierza, a potem przez kilkanaście lat jako profesor gimnazjalny w Mikołowie. Habilitował się w czerwcu 1950 r. na Wydziale Humanistycznym Uniwersytetu Wrocławskiego. Na Uniwersytecie Wrocławskim S. Bąk pracował do przejścia na emeryturę. Już za życia był postacią owianą legendą. Zasłużył się jako dialektolog i etnograf, przede wszystkim jako wybitny znawca i badacz polskich gwar Dolnego Śląska (zob. Miodek 1982). W swoim dorobku S. Bąk ma również prace dotyczące innych języków słowiańskich, w tym skrypt do nauki języka staro-cerkiewno-słowiańskiego. Warto odnotować, że w kwestionariuszu osobowym z 1948 r. w rubryce zawierającej pytanie o to, jakie zna instytucje naukowe z dziedziny swoich zainteresowań naukowych, S. Bąk na pierwszym miejscu podał Studium Słowiańskie UJ w Krakowie.

Z początkiem listopada 1946 r. pracę we Wrocławiu podjął W. Kuraszkiewicz, absolwent Uniwersytetu Jana Kazimierza we Lwowie, gdzie w 1929 r. uzyskał doktorat. Jego mistrzami byli Tadeusz Lehr-Spławiński i Jan Janów. Dalsze studia slawistyczne odbywał w Krakowie, także pod kierunkiem T. Lehra-Spławińskiego, K. Nitscha i J. Rozwadowskiego. Habilitował się z językoznawstwa słowiańskiego na Uniwersytecie Jagiellońskim w roku 1934. W tym samym roku jako stypendysta wyjechał do Wiednia i tam przez jeden trymestr pracował w Seminarium Słowiańskim Mikołaja Trubieckiego (1890-1938), a później także przez trymestr w Pradze, uczestnicząc w seminariach Miloša Weingarta i Oldřicha Hujera. Przez pewien czas pracował na Uniwersytecie Jana Kazimierza we Lwowie i na Uniwersytecie Jagiellońskim. Od roku 1936 do 1939 był profesorem Katolickiego Uniwersytetu Lubelskiego. Wojnę spędził w obozie koncentracyjnym w Oranienburgu. We Wrocławiu Kuraszkiewicz objął wakującą Katedrę Językoznawstwa Słowiańskiego i kierownictwo Instytutu. W momencie przyjazdu do Wrocławia uczony był już autorem prac dotyczących historii i dialektów języka polskiego, języka połabskiego oraz języków ruskich, w szczególności ukraińskiego. We Wrocławiu pracował do roku 1951, później przeniósł się na Uniwersytet im. Adama Mickiewicza w Poznaniu.

Latem 1947 r., po dwóch latach służby dyplomatycznej, przyjechał z Belgradu do Wrocławia historyk literatur słowiańskich M. Jakóbiec, którego „Stanisław Rospond raz po raz ponaglał listami do przyjazdu” (Jakóbiec 2009: 207). Po przyjeździe do Wrocławia M. Jakóbiec objął Katedrę Literatury Rosyjskiej i Innych Literatur Słowiańskich. Później, w roku 1950, w wyniku połączenia tej katedry z Katedrą Filologii Wschodniosłowiańskiej powstała Katedra Filologii Rosyjskiej, zasłużona poprzedniczka Instytutu Filologii Słowiańskiej ${ }^{8}$. Instytucjami tymi kierował M. Jakóbiec nieprzerwanie do 1971 r., w sposób wybitny przyczyniając się do ich rozwoju.

Ponadto we Wrocławiu pracowali krótko Przemysław Zwoliński i Zbigniew Gołąb. P. Zwoliński, absolwent filologii polskiej i słowiańskiej na Uniwersytecie Jana

8 O badaniach w zakresie językoznawstwa słowiańskiego prowadzonych w Katedrze Filologii Rosyjskiej, poprzedniczce utworzonego w 1969 r. Instytutu Filologii Słowiańskiej, zob. Sokołowski 2015. 
Kazimierza we Lwowie, pracował we Wrocławiu bardzo krótko, od 19 października 1945 r. do 15 stycznia 1946 r., po czym przeniósł się do Warszawy. Jako stypendysta rządu bułgarskiego przebywał w latach 1932-1934 w Bułgarii na Uniwersytecie Sofijskim im. św. Klemensa z Ochrydy, gdzie studiował język bułgarski oraz prowadził kurs języka polskiego dla studentów tamtejszej slawistyki. Pracę na Uniwersytecie Wrocławskim podjął już w październiku 1945 r., bezpośrednio po demobilizacji z Wojska Polskiego, w którym służył od listopada 1944 r. Z chwilą zatrudnienia na Uniwersytecie Wrocławskim wystąpił do dziekana Wydziału Humanistycznego z pismem i prośbą o wyrażenie zgody na prowadzenie lektoratu języka bułgarskiego. W uzasadnieniu Zwoliński napisał, że student polonistyki powinien znać po jednym języku z każdej podgrupy języków słowiańskich. W Archiwum Uniwersytetu Wrocławskiego zachowała się kopia pisma poświadczającego, że „Ob. Zwoliński Przemysław jest lektorem języka bułgarskiego"'.

Jesienią 1945 r. do Wrocławia przyjechał Z. Gołąb i już 1 listopada tegoż roku, a więc jeszcze jako student, zatrudniony został na stanowisku młodszego asystenta w Katedrze Języka Polskiego, którą kierował S. Rospond. W grudniu 1947 r. Z. Gołąb obronił z wynikiem bardzo dobrym pracę magisterską o temacie Księga henrykowska. Opracowanie językowe (promotor S. Rospond) i z takim samym wynikiem złożył egzamin końcowy, uzyskując dyplom magistra w zakresie filologii polskiej. Materiały zachowane w Archiwum Uniwersytetu Wrocławskiego świadczą o tym, że młody uczony już podczas studiów miał skrystalizowane poglądy co do swej przyszłości naukowej. W kwestionariuszu z 12 czerwca 1948 r. napisał, że w ciągu najbliższych dwóch lat zamierza przygotować rozprawę doktorską nt. Dialekty wymarlych Stowian połabskich $w$ świetle toponomastyki średniowiecznej. Jako motywy wyboru tematu podał zainteresowanie Słowiańszczyzną Zachodnią. Jednym z przejawów tego zainteresowania była aktywność Gołąba jako prezesa okręgowego koła Akademickiego Związku Przyjaciół Łużyc „Prołuż” ${ }^{10}$. W tym samym kwestionariuszu w rubryce „Zamierzenia naukowe na przyszłość” Gołąb napisał, że po uzyskaniu doktoratu zamierza zająć się badaniami językowo-etnograficznymi Słowiańszczyzny Bałkańskiej. Jak wiadomo, w dziedzinie bałkanistyki zyskał międzynarodową renomę. Charakteryzując osiągnięcia Gołąba w „działalności naukowej, dydaktycznej i społecznej”, W. Kuraszkiewicz napisał, że wyróżnia się on „wybitnie w dziedzi-

9 W Archiwum zachowało się też zaświadczenie wydane 19 października 1945 r. przez pełnomocnika Ministra Oświaty we Wrocławiu stwierdzające, że „[...] ob. mgr Przemysław Zwoliński urodzony w Opawie (Czechosłowacja), zamieszkały we Wrocławiu [...] jest pracownikiem Grupy Naukowo-Kulturalnej m. Wrocławia. Ważność do dnia 31 X 1945" (AUWr, Sygn. RK-120/Przemysław Zwoliński).

10 Oprócz tego działało we Wrocławiu Akademickie Stowarzyszenie Łużyczan Studentów Wyższych Uczelni we Wrocławiu „Lusatia”. Jego członkiem honorowym był rektor Uniwersytetu Wrocławskiego prof. S. Kulczyński. 
nie studiów językoznawczych słowiańskich" ${ }^{11}$. Na Uniwersytecie Gołąb pracował do 30 września 1948 r. Pobyt w więzieniu uniemożliwił młodemu uczonemu dalszą pra$\mathrm{cę}^{12}$. Z zachowanych materiałów dowiadujemy się tylko, że w odpowiedzi na zapytanie władz Uniwersytetu Wrocławskiego dotyczące dalszego zatrudnienia Gołąba

Ministerstwo Oświaty nie może wyrazić zgody na zatrudnienie ob. mgr. Zbigniewa Gołąba w charakterze kontraktowego st. asystenta przy Katedrze Języka Polskiego na Wydziale Humanistycznym Uniwersytetu Wrocławskiego we Wrocławiu ${ }^{13}$.

Charakterystyka pierwszych lat wrocławskiej slawistyki językoznawczej byłaby niepełna, gdybyśmy nie wspomnieli o kilku innych uczonych związanych wcześniej ze Lwowem i Krakowem, którzy tuż po wojnie podjęli pracę na Uniwersytecie Wrocławskim. Przede wszystkim trzeba tu wymienić profesora Uniwersytetu Jana Kazimierza we Lwowie, wybitnego indoeuropeistę i teoretyka języka Jerzego Kuryłowicza, który od 1946 do 1948 r. kierował na Uniwersytecie Wrocławskim Katedrą Językoznawstwa Porównawczego, przemianowaną później na Katedrę Językoznawstwa Ogólnego. Przez kilka następnych lat (do 1952 r.) J. Kuryłowicz prowadził we Wrocławiu wykłady w trybie godzin zleconych. Jego obecność wywarła znaczący wpływ na ukształtowanie się wrocławskiego środowiska językoznawczego. Po odejściu Kuryłowicza z Uniwersytetu Wrocławskiego Katedrę objął jego uczeń Leon Zawadowski.

Oprócz J. Kuryłowicza w latach 1945-1950 na Uniwersytecie Wrocławskim pracowali: Ananiasz Zajączkowski, absolwent studiów orientalistycznych na Uniwersytecie Jagiellońskim, gdzie w 1929 r. uzyskał doktorat, i afrykanista Roman Stopa, który jednak poprzestał na wygłoszeniu tylko kilku wykładów.

W roku 1957 po studiach na Uniwersytecie Jagiellońskim i kilku latach pracy w Zakładzie Językoznawstwa Polskiej Akademii Nauk w Krakowie pracę we Wrocławiu podjął ostatni z wrocławskich wychowanków Studium Słowiańskiego UJ, Antoni Furdal, uczeń K. Nitscha i T. Lehra-Spławińskiego. W komentarzu do bibliografii swoich prac Furdal wspominał: „W roku 1957 otrzymałem pracę w Uniwersytecie Wrocławskim, rok później zamieszkałem we Wrocławiu. Był tu potrzebny polonista i slawista zarazem. Przyjął mnie do swej katedry profesor Stanisław Rospond"

11 W kwestionariuszu osobowym z 12 czerwca 1948 r. w rubryce „6. Szczegółowy przebieg studiów dotychczasowych” Gołąb podaje: „Od 1943 do 1946 włącznie studia w zakresie filologii polskiej i słowiańskiej w Krakowie na Uniw. Jagiell. (dwa lata konspiracyjnie); dyplom magisterski (wraz z pracą) na Uniw. Wrocław. w 1947" (AUWr, Sygn. 138/Zbigniew Gołąb).

12 Profesora Z. Gołąba poznałem w sierpniu 1978 r. w Ochrydzie na Seminarium Języka, Literatury i Kultury Macedońskiej. Wiedząc, że jestem z Wrocławia, chętnie dzielił się ze mną wspomnieniami z czasów, gdy był studentem i pracownikiem Uniwersytetu Wrocławskiego. We wspomnieniach tych nie zabrakło też opowieści dotyczących dramatycznych momentów jego życia z czasów II wojny światowej oraz historii o aresztowaniu i pobycie w komunistycznym więzieniu. AUWr, Sygn. 138/Zbigniew Gołąb, s. 23. 
(Furdal 2009: 20). W momencie przyjazdu do Wrocławia A. Furdal miał już w dorobku napisaną pod kierunkiem Nitscha i opublikowaną w roku 1955 pracę Mazowieckie dyspalatalizacje spółgłosek wargowych miękkich. W latach 1953-1956 w Katedrze Filologii Słowiańskiej UJ odbył pod opieką T. Lehra-Spławińskiego studia aspiranckie, uwieńczone rozprawą Rozpad języka prasłowiańskiego $w$ świetle rozwoju głosowego. Obrona rozprawy doktorskiej odbyła się w roku 1960 na Uniwersy tecie im. Adama Mickiewicza w Poznaniu, a promotorem był W. Kuraszkiewicz ${ }^{14}$. Habilitował się w $1965 \mathrm{r}$. na podstawie pracy O przyczynach zmian głosowych w języku polskim. We Wrocławiu A. Furdal pracował w Katedrze Języka Polskiego, a później, w latach 1970-1984, kierował Katedrą Językoznawstwa Ogólnego. Po przeniesieniu się do Wyższej Szkoły Pedagogicznej w Opolu (od 1994 r. Uniwersytet Opolski) zorganizował w Instytucie Filologii Polskiej specjalność bohemistyczną, a później Katedrę Slawistyki, którą kierował do 1992 r. (Sokołowski 2019).

Wrocławscy lingwiści nieraz mówili i pisali o związkach łączących ich z Uniwersytetem Jagiellońskim i z krakowskimi uczonymi, którzy w pierwszych latach powojennych wspierali ich swoim autorytetem. Tuż po wojnie odwiedził Wrocław T. Lehr-Spławiński. W dniu 10 czerwca 1946 r. jako przedstawiciel Polskiej Akademii Umiejętności wziął udział w inauguracyjnym zebraniu Wrocławskiego Towarzystwa Naukowego i wygłosił przemówienie.

$\mathrm{W}$ ostatnich latach sporo pisał i mówił na ten temat A. Furdal. W artykule Ze wspomnień. Początki moich studiów w Krakowie pisał:

zaraz po wojnie Kraków był wymarzonym miejscem do studiowania. Na UJ i do PAU wrócili już uczeni, którzy wykładali tam przed wojną, przybyło wielu rozproszonych po świecie. Samo zaś miasto wyglądało tak, jakby miniona niedawno wojna w ogóle go nie tknęła (Furdal 2014).

W tym samym artykule wspominał znakomitych uczonych, historyków literatury polskiej i innych literatur słowiańskich oraz językoznawców, którzy podczas jego studiów wykładali na Uniwersytecie Jagiellońskim. Oprócz swoich mistrzów, Kazimierza Nitscha i Tadeusza Lehra-Spławińskiego, wymienił Witolda Taszyckiego, Zenona Klemensiewicza, Franciszka Sławskiego, Jerzego Kuryłowicza, Tadeusza

$14 \mathrm{~W}$ artykule A. Furdala Postać profesora Władysława Kuraszkiewicza na tle życia naukowego $w$ Polsce znajdujemy o tym wydarzeniu następującą wzmiankę: „Dawno temu bowiem wydarzyło mi się w życiu tak, że zamknęła się przede mną droga naukowa. Człowiekiem, który zgodził się przyjść mi w tym momencie z pomocą był właśnie profesor Kuraszkiewicz. Przyjechałem do niego $\mathrm{z}$ gotową już pracą doktorską i wtedy odbyła się u Niego $\mathrm{w}$ domu moja pierwsza $\mathrm{z}$ Nim rozmowa, którą wedle przyszłej »typologii rozmów można by określić jako pełnokontaktową i multitematyczną, z przerwami na parzenie kawy i herbaty, z nieodzownymi dłuższymi chwilami milczenia. Było to dla mnie także coś w rodzaju egzaminu ze slawistyki, ale również z wyobrażeń o ludziach i świecie. Finałem stała się niebawem moja obrona doktorska w niedalekim stąd Collegium Minus, naturalnie z Profesorem Kuraszkiewiczem jako promotorem” (Furdal 1999: 30). 
Milewskiego. Szczególne miejsce w jego wspomnieniach zajmuje Kazimierz Nitsch, który był „osobowością przyćmiewającą innych, zarówno wiedzą, jak i swoim sposobem bycia" (ibid.: 116). K. Nitsch jest niewątpliwie pierwowzorem postaci profesora w opowiadaniu Furdala Ziarenko ze zbioru Opowiadania profesora F. (Furdal 2004). $\mathrm{Na}$ początku 2013 r. zaprosiłem prof. Furdala do wygłoszenia referatu na jednym ze Slawistycznych Spotkań Językoznawczych, które odbywały się raz w miesiącu w Instytucie Filologii Słowiańskiej Uniwersytetu Wrocławskiego. Profesor chętnie przyjął zaproszenie i 13 maja 2013 r. w wypełnionej po brzegi sali wygłosił wykład: Początki moich studiów na Uniwersytecie Jagiellońskim ${ }^{15}$.

$\mathrm{Na}$ zakończenie, zamiast podsumowania, pozwolę sobie raz jeszcze przywołać słowa A. Furdala, który charakteryzując Wrocław jako swoje nowe miejsce pracy, a Ziemie Zachodnie i Północne jako swoją małą ojczyznę, tak pisał o swoich mistrzach i związkach naukowych łączących wrocławskich językoznawców z Krakowem i Lwowem:

Rozstawałem się z Krakowem, mając przed oczyma ten piękny i jakże krótki na tle całego życia czas, gdy było mi dane przebywać w wymarzonym przed laty środowisku naukowym i stykać się na co dzień z polonistami, historykami, filozofami, a przede wszystkim z językoznawcami, wśród których był Kazimierz Nitsch. We Wrocławiu okazało się jednak, że od Nitscha nie odszedłem daleko. Zewnętrznie świat był inny, uniwersytet ulokowany w poaustriackim jeszcze kolegium jezuickim, polonistyka w dawnym pałacu książąt brzeskich, ale w samym środowisku naukowym było trochę tak jak w Krakowie. W każdym zaś razie w mojej dziedzinie dwaj moi mistrzowie, Kazimierz Nitsch i Tadeusz Lehr-Spławiński, byli bez przerwy obecni. Do ich badań nawiązywali profesorowie wykształceni i pracujący dawniej w Krakowie i Lwowie: Stanisław Rospond, Stanisław Bąk i Leszek Ossowski. Główne tematy, jakie rozwijał Kazimierz Nitsch w ostatnich latach, dotyczyły przede wszystkim historii języka polskiego wraz z problemem pochodzenia języka literackiego, współczesnego języka polskiego i naturalnie dialektologii polskiej i słowiańskiej. Wszystko to wówczas było przedmiotem wykładów i zebrań naukowych, cieszących się zainteresowaniem nie tylko językoznawców. W niekończących się debatach i dyskusjach stale pojawiało się nazwisko Nitscha, a jego autorytet nie był mniejszy niż w rodzinnym Krakowie.

Przyznać muszę, że tak naprawdę dopiero wtedy zdałem sobie sprawę z miejsca i znaczenia Kazimierza Nitscha w polskim językoznawstwie. Nie tylko we Wrocławiu, ale właściwie w całej Polsce wykładali i szerzyli wiedzę lingwistyczną jego uczniowie i współpracownicy z okresu międzywojennego, a przynajmniej kontynuatorzy jego dzieła naukowego (Furdal 2011: 64).

Profesor A. Furdal, z którym miałem szczęście przez kilka dziesięcioleci współpracować, do ostatnich lat życia utrzymywał bliskie związki z Uniwersytetem Jagiel-

15 W ostatnich latach życia A. Furdal pracował nad książką Typologia wspomnień, zawierającą m.in. rozdziały dotyczące jego pobytu w Krakowie, Wrocławiu i innych miejscach. Można żywić nadzieję, że za jakiś czas wspomnienia te zostaną ogłoszone drukiem. 
lońskim i z Polską Akademią Umiejętności. Był członkiem Komisji Środkowoeuropejskiej PAU, aktywnie uczestniczył w jej posiedzeniach, a po powrocie dzielił się ze mną wrażeniami z pobytu w Krakowie. Kiedy jesienią 2018 r. poinformowałem go, że zostałem zaproszony do wzięcia udziału w uroczystości i sesji naukowej zorganizowanej przez Instytut Filologii Słowiańskiej UJ z okazji jubileuszu dwóchsetlecia krakowskiej slawistyki, bardzo się ucieszył i prosił mnie o przekazanie z tej okazji gratulacji i pozdrowień krakowskim kolegom slawistom. Po moim powrocie z Krakowa Profesor zaprosił mnie do swojego domu, gdzie po wysłuchaniu informacji o przebiegu tego pięknego jubileuszu po raz kolejny dzielił się ze mną wspomnieniami z czasów swoich studiów na Uniwersytecie Jagiellońskim.

\section{Źródła}

Bąk S., AUWr, sygn. 138/443.

Furdal A., AUWr, sygn. 28/39.

Gołąb Z., AUWr, sygn. 138.

Kuraszkiewicz W., AUWr, sygn. RK-120.

Kuryłowicz J., AUWr, sygn. RK-120.

Ossowski L., AUWr, sygn. 138/.

Rospond S., AUWr, sygn. 138/.

Zwoliński P., AUWr, sygn. RK-120.

\section{Literatura}

BĄK S., 1966, Stanisław Rospond - człowiek i uczony, [w:] M. Adamus (red.), Studia językoznawcze poświęcone profesorowi doktorowi Stanisławowi Rospondowi, Wrocław, s. 7-21.

Dekret: Dekret z dn. 24 sierpnia 1945 r. o przekształceniu Uniwersytetu Wrocławskiego i Politechniki Wrocławskiej na polskie państwowe szkoły akademickie, Dz.U. 1945 nr 34, poz. 207.

Furdal A., 1999, Postać profesora Władysława Kuraszkiewicza na tle życia naukowego w Polsce, „Poznańskie Spotkania Językoznawcze. Prace Komisji Językoznawczej - Poznańskie Towarzystwo Przyjaciół Nauk. Wydział Filologiczno-Filozoficzny”, t. 5, cz. 1, Poznań, s. 25-31.

Furdal A., 2004, Opowiadania profesora F., Wrocław.

Furdal A., 2009, Mój komentarz do bibliografii, [w:] M. Sarnowski, W. Wysoczański (red.), Wyraz i zdanie w językach słowiańskich. Opis, konfrontacja, przekład 7, „Acta Universitatis Wratislaviensis” 3159, „Slavica Wratislaviensia” 150, Wrocław, s. 19-23.

Furdal A., 2011, Profesor Nitsch w moich wspomnieniach, czyli Kazimierz Nitsch na tle kraju i epoki, [w:] R. Majkowska, T. Filip (red.), Kazimierz Nitsch 1874-1958: materiały z posiedzenia naukowego w dniu 20 czerwca 2008 r., „W Służbie Nauki” nr 18, Kraków, s. 63-69.

Furdal A., 2014, Ze wspomnień. Początki moich studiów w Krakowie, [w:] I. Łuczków, M. Sarnowski (red.), Wyraz i zdanie w językach słowiańskich: opis, konfrontacja, prze- 
kład 8, „Acta Universitatis Wratislaviensis” 3578, „Slavica Wratislaviensia” 159, Wrocław, s. $111-120$.

JАко́вIEC M., 2009, Z daleka i z bliska: wspomnienia i pamiętniki w biografię zebrane i uporządkowane przez córkę Milicę Jakóbiec-Semkowowa, „Acta Universitatis Wratislaviensis” 3074, „Biografie Uczonych Wrocławskich”, Wrocław.

ŁoвоDZIŃsKa R., 2004, Stanisław Rospond - wielki historyk polszczyzny śląskiej, [w:] M. Hałub, A. Mańko-Matysiak (red.), Śląska Republika Uczonych, t. 1, Wrocław, s. 695-702. Łoвodzińska R., 2010, Stanisław Rospond - onomasta i miłośnik nazw, [w:] J. Nowosielska-Sobel, G. Strauchold, W. Kucharski (red.), Nazwa dokumentem przeszłości regionu. Tom poświęcony Wielkiemu Profesorowi Stanisławowi Rospondowi, „Spotkania Dolnośląskie", t. 5, Wrocław, s. 15-20.

ŁoвodZIŃska R., 2017, Naukowo-badawcze postulaty Profesora Stanisława Rosponda i ich realizacje w onomastyce polskiej i słowiańskiej, [w:] Z. Zaron, M. Grochowski (red.), Znaki pamięci 2: spuścizna językoznawców polskich drugiej połowy XX wieku, Warszawa, s. $87-95$.

MiodeK J., 1982, Stanisław Bąk, „Lud” 66, s. 417-419.

Rospond S., 2010, Droga do Ślaska, Kraków.

SKarżYŃski M., 2019, Geneza i początki Studium Słowiańskiego UJ, „LingVaria” nr 1 (27), s. 11-33, https://doi.org/10.12797/LV.14.2019.27.01.

SокоџошSкі J., 2015, Językoznawstwo słowiańskie na Uniwersytecie Wrocławskim (19452010), [w:] J. Harasimowicz (red.), Ksiega pamiątkowa jubileuszu 20o-lecia utworzenia Państwowego Uniwersytetu we Wrocławiu, t. 4: Uniwersytet Wrocławski w kulturze europejskiej XIX i XX wieku: materiały międzynarodowej konferencji naukowej, Wrocław 4-7 października 2011 r., "Acta Universitatis Wratislaviensis” 3527, Wrocław, s. 613-620. SoкоŁowsкi J., 2019, Antoni Furdal (1928-2019), „Rocznik Slawistyczny”, t. LXVIII, s. 3-11. WrZEsiŃsKi W., 2002, Uniwersytet Wrocławski w latach 1945-2002, [w:] T. Kulak, M. Pater, W. Wrzesiński, Historia Uniwersytetu Wrocławskiego 1702-2002, „Acta Universitatis Wratislaviensis" 2402, Wrocław, s. 201-377.

\section{Cracow-Lviv Roots of Wrocław Slavic Studies Summary}

The paper discusses the beginnings of Polish and Slavic linguistics at the Univertsity of Wroclaw directly after World War II. It was created by young scholars, linguists, Slavicists and Polonists, who gained their education and academic degrees at the Jagiellonian University and the John Casimir University in Lviv. This group included primarily S. Rospond, L. Ossowski, W. Kuraszkiewicz, S. Bąk, all educated before the war, as well as A. Furdal, much younger than the others and educated already after the war. These scholars received their education under the guidance of the best Polish linguists, Slavicists, Polonists, and Indo-Europeanists. In addition, the paper presents basic information about preparations made in Cracow during the war, to create Polish and Slavic studies at the University of Wroclaw. 